\title{
Methane oxidation in permeable sediments at hydrocarbon seeps in the Santa Barbara Channel, California
}

\author{
T. Treude ${ }^{1,2}$ and W. Ziebis ${ }^{2}$ \\ ${ }^{1}$ University of Southern California, Department of Marine Environmental Biology, Los Angeles, CA, USA \\ ${ }^{2}$ present address: Leibniz Institute of Marine Sciences (IFM-GEOMAR), Kiel, Germany
}

Received: 3 March 2010 - Published in Biogeosciences Discuss.: 17 March 2010

Revised: 11 September 2010 - Accepted: 19 September 2010 - Published: 13 October 2010

\begin{abstract}
A shallow-water area in the Santa Barbara Channel, California, known collectively as the Coal Oil Point seep field, is one of the largest natural submarine hydrocarbon emission areas in the world. Both gas and oil are seeping constantly through a predominantly sandy seabed into the ocean. This study focused on the methanotrophic activity within the surface sediments $(0-15 \mathrm{~cm})$ of the permeable seabed in the so-called Brian Seep area at a water depth of $\sim 10 \mathrm{~m}$. Detailed investigations of the sediment biogeochemistry of active gas vents indicated that it is driven by fast advective transport of water through the sands, resulting in a deep penetration of oxidants (oxygen, sulfate). Maxima of microbial methane consumption were found at the sediment-water interface and in deeper layers of the sediment, representing either aerobic or anaerobic oxidation of methane, respectively. Methane consumption was relatively low $\left(0.6-8.7 \mathrm{mmol} \mathrm{m}^{-2} \mathrm{~d}^{-1}\right)$ in comparison to gas hydratebearing fine-grained sediments on the continental shelf. The low rates and the observation of free gas migrating through permeable coastal sediments indicate that a substantial proportion of methane can escape the microbial methane filter in coastal sediments.
\end{abstract}

\section{Introduction}

Coal Oil Point seep field, in the Santa Barbara Channel, California, is one of the largest natural submarine oil and gas emission areas in the world (Allen and Mikolaj, 1970; Valentine et al., 2010). Hydrocarbons are leaking from a reservoir $\sim 1500 \mathrm{~m}$ below the seafloor. Seeps occur along fractures in shallow water from the shoreline to $60 \mathrm{~m}$ water depths. Gas and oil are constantly seeping through a predom-

Correspondence to: $\mathrm{T}$. Treude

(ttreude@ifm-geomar.de) inantly sandy seabed into the ocean at estimated flux rates of $1.7 \times 10^{5} \mathrm{~m}^{3} \mathrm{~d}^{-1}$ of hydrocarbon gases (88\% methane) and $16 \mathrm{~m}^{3} \mathrm{~d}^{-1}$ of crude oil (Hornafius et al., 1999). The intensity of seepage is variable and may be linked to tidal changes or seismic activity (Boles and Clark, 2001). Methane plumes have been observed in the water column in an area of $\sim 70 \mathrm{~km}^{2}$ with emission rates of $1.1 \times 10^{3} \mathrm{~m}^{3} \mathrm{CH}_{4} \mathrm{~d}^{-1}$. This methane flux into the atmospheres is estimated to account for approximately $1 \%$ of the total methane export across the sediment-water interface (Mau et al., 2007). The remaining 99\% of methane that is emitted from the seafloor are assumed to be consumed by methanotrophic bacteria in surface sediments or in the water column.

The present study focused on methanotrophic activity and biogeochemical processes in the sediments of a study area known as "Brian Seep", which is located off the coast of Coal Oil Point at water depths around $10 \mathrm{~m}$ (Kinnaman et al., 2010; Kinnaman et al., 2007). In this coastal area, sediments consist of permeable sand (permeability $\sim 10^{-11} \mathrm{~m}^{2}$, see results). Sand enables a much faster advective transport of fluids and gases through the sediment matrix compared to fine-grained cohesive clay found in benthic environments on the continental margins (Huettel et al., 2003; Huettel et al., 1998; Ziebis et al., 1996). In addition, water movements induced by waves and tidal currents constantly reshape the sediment surface topography (Precht et al., 2004). It was the aim of the present study to investigate how gas venting through the permeable seabed impacts aerobic and anaerobic microbial oxidation of methane. In gassy sediments, both processes are controlled by the supply of electron acceptors, i.e., oxygen and sulfate, respectively (Nauhaus et al., 2002; Treude, 2003a; Niemann et al., 2006), hence, we expected to find differences in their magnitude and distribution compared to fine-grained sediments that dominate deeper seep habitats of the continental margins.

Published by Copernicus Publications on behalf of the European Geosciences Union. 


\section{Materials and methods}

\subsection{Sediment sampling}

Sediment samples were taken by SCUBA diving in the Brian Seep area $\left(34^{\circ} 24.109^{\prime} \mathrm{N}, 119^{\circ} 49.917^{\prime} \mathrm{W}\right.$, water depth $\left.10 \mathrm{~m}\right)$ using two sizes of polycarbonate core liners (inner diameter/total length: $5.4 / 40$ and $2.5 / 30 \mathrm{~cm}$, respectively). Core liners were pushed by hand and gently hammered into the sediment using rubber mallets. In general, not more than $\sim 15 \mathrm{~cm}$ of sediment could be retrieved by coring because the sandy surface coverage was followed by a gravel bed, impeding a deeper penetration. Core liners were closed with rubber stoppers under water and additionally sealed with tape immediately after surfacing. The larger liners had a valve that was opened while the top or bottom stoppers were pushed inside. Samples were taken in April, June and November of 2006. In April, a horizontal transect was sampled at 0, 20, $50,100,200$, and $400 \mathrm{~cm}$ distances from a gas vent, which showed a continuous release of gas visible as streams of bubbles (methane content $\sim 91 \%$, Kinnaman et al., 2010). At the $400 \mathrm{~cm}$ distance, a new gas bubble stream emerged from the sediment, when core liners were forced into the sediment. In June, samples were taken at two different gas vents that were approximately $20 \mathrm{~m}$ apart. Cores were taken as close to the central gas venting conduits as possible. In November, samples were taken along a shorter transect at $0,20,40$, and $60 \mathrm{~cm}$ distances away from another gas vent. Water temperatures in the seep area varied between 11,14 , and $15^{\circ} \mathrm{C}$ in April, June and November 2006, respectively (NOAA National Data Buoy Center, Station 46045). No oil leaks or pockets of oil in sediments were discovered during sampling. Immediately after retrieval, sediment cores were transported to the shore by boat and from the shore to the laboratory by car for further processing. During transport, disturbances were kept to a minimum and cores were stored in cooling boxes to prevent heating. In the following, the sampling locations will be abbreviated with the distance from the gasventing spot in $\mathrm{cm}$ followed by the abbreviation of the month (April and November), for example: 0-cm-April and 20-cmNovember. In June, the two vents that were sampled will be called Vent A and Vent B.

\subsection{Microprofiling}

Oxygen, $\mathrm{H}_{2} \mathrm{~S}$ and $\mathrm{pH}$ microgradients were measured with microelectrodes at room temperature $\left(19^{\circ} \mathrm{C}\right)$ in intact large cores (i.d. $5.4 \mathrm{~cm}$ ) $2-4 \mathrm{~h}$ after sampling at the seafloor. During microsenor profiling, cores were steadied and kept at stable room temperature $\left(19^{\circ} \mathrm{C}\right)$. The oxygen sensors were Clark-type amperometric electrodes with a built-in reference and a guard cathode (Unisense OX50; Revsbech, 1989) with a tip diameter of $50 \mu \mathrm{m}$, a stirring sensitivity of $1 \%$ and a $90 \%$ response time $<1 \mathrm{~s}$. The electrodes respond linearly to the dissolved oxygen concentrations in sea water. A two-point calibration was performed by inserting the oxygen electrode into a calibration chamber filled with water from the sampling site, which was purged with air (100\% saturation) or nitrogen ( $0 \%$ saturation) at the in situ temperature. The $\mathrm{H}_{2} \mathrm{~S}$ microsensor used in the analysis was a miniaturized amperometric sensor with an internal reference and a guard electrode (Unisense ${ }^{\circledR}$ H2S25; Jeroschewsky et al., 1996; Kühl et al., 1998). The sensor had a long $(5 \mathrm{~cm})$ tapered tip with a tip diameter of $50 \mu \mathrm{m}$. The response time was $<2 \mathrm{~s}$. Total sulfide concentrations were calculated using $\mathrm{pH}$ values measured in tandem with the $\mathrm{H}_{2} \mathrm{~S}$ profiles using long needle combination electrodes (Diamond General ${ }^{\circledR}$ ), which were connected to a high-impedance $\mathrm{mV}$-meter (Unisense ${ }^{\circledR}$ PHM210). The $\mathrm{pH}$ electrode was calibrated using standard $\mathrm{pH}$ buffer solutions $\left(\mathrm{VWR}^{\circledR}\right)$. Calibration of the $\mathrm{H}_{2} \mathrm{~S}$ microsensor was performed with $\mathrm{Na}_{2} \mathrm{~S}$ standards of known concentrations measured by colorimetric analysis (Cline, 1969). Signals of the amperometric sensors were amplified and transformed to millivolt $(\mathrm{mV})$ by a 2-channel picoammeter (PA 2000, Unisense ${ }^{\circledR}$ ), and directly recorded on a computer using the software Profix $\left(\right.$ Unisense $\left.^{(}\right)$). Cathodes were polarized against an internal reference. All electrodes were attached to a micromanipulator and moved vertically into the sediment via a computer-controlled motor (Unisense ${ }^{\circledR}$ MC18011).

\subsection{Whole sediment sampling}

Sediment samples for the determination of methane concentration, porosity, density, grain size, permeability, and fluorescence in situ hybridization (FISH) were taken with large core liners (i.d. $5.4 \mathrm{~cm}$ ) and sectioned in 1-cm-intervals $2-4 \mathrm{~h}$ after sampling at the seafloor. For the analysis of methane, five $\mathrm{cm}^{3}$ sediment were taken with cut-off syringes and transferred into $60 \mathrm{ml}$ glass vials filled with $35 \mathrm{ml}$ sodium hydroxide $(2.5 \% w / w)$. The vials were closed quickly with butyl rubber stoppers, sealed with aluminum crimps, and shaken thoroughly to equilibrate the porewater methane into the headspace.

Methane concentrations were determined by injection of $200 \mu \mathrm{l}$ headspace into a gas chromatograph (Shimadzu, Model 2014) equipped with a packed stainless steel Supelco Custom Column (50/50 mixture, 80/100 Porapak N support, 80/100 Porapak Q column, $6 \mathrm{ft} \times 1 / 8 \mathrm{in}$ ) and a flame ionization detector. The carrier gas was helium at a flow rate of $30 \mathrm{ml} \mathrm{min}{ }^{-1}$. The column temperature was $60^{\circ} \mathrm{C}$. Methane concentrations were calculated per volume sediment. Carbon isotope ratios of methane were determined with inline ratio monitoring mass spectrometry as described by Rice et al. (2001). For porosity and density determination, approximately five $\mathrm{cm}^{3}$ sediment were transferred into preweighed $15 \mathrm{ml}$ plastic centrifuge vials with a volume scale bar and closed with a plastic screw cap. The vials were centrifuged $(2200 \mathrm{~g}, 10 \mathrm{~min})$, weighed, filled with water to 
a defined volume, weighed again, dried and weighed a third time. Density was calculated by dividing the sediment wet weight by the sediment volume (sediment volume with added water minus volume of added water). Porosity was calculated by dividing the porewater volume (wet weight minus dry weight) by the sediment volume. For the determination of grain size and permeability the dried sediment was finally sieved through different mesh sizes $(1000,500$, 250, and $125 \mu \mathrm{m}$ ) and weighed. Percentages of grain sizes were determined from weight ratios. Permeability of the sediment was calculated according to Krumbein and Monk (1943). The applied equation produces permeability values that significantly correlate with measured one, but can on average reach values 4 times higher, which should be considered in the interpretation of the gained data (Rusch et al., 2001). For FISH analyses, $0.5 \mathrm{~cm}^{3}$ of each sediment slice was transferred into $1.5 \mathrm{ml}$ formaldehyde (final concentration 3\%) and fixed for 2-4h. After fixation, the sample was washed twice with $1 \times$ PBS $\left(10 \mathrm{mmol} \mathrm{L}^{-1}\right.$ sodium phosphate, $\left.130 \mathrm{mmol} \mathrm{L}^{-1} \mathrm{NaCl}\right)$ and finally stored in 1xPBS/EtOH (1:1) at $-25^{\circ} \mathrm{C}$.

\subsection{Porewater extraction and analyses}

Porewater samples are difficult to retrieve from highly permeable sandy sediment cores by normal core slicing and porewater pressing without creating substantial disturbances in the geochemical profile. It is best to obtain porewater samples from intact cores by simultaneous extraction from all depths (Seeberg-Elverfeldt et al., 2005; Shotbolt, 2010). We used a porewater extraction device designed for sandy sediments (Ziebis, unpublished). The cores were taken with liners (i.d. $5.4 \mathrm{~cm}$ ) that were perforated with rows of siliconfilled holes in $2-\mathrm{cm}$ vertical intervals on opposite sides and alternating depth, to allow a depth resolution of $1 \mathrm{~cm}$. The core was held in place so that double-sided needles, which were mounted horizontally on sliding racks to both sides of the core, could be pushed simultaneously, i.e. at all depths, into the sediment. The other side of the needles was sealed with a rubber membrane. Vacutainers that were also mounted horizontally in racks to both sides, were pushed onto the needles so that the membrane was pushed aside and the needle penetrated through the stopper. By the under-pressure in the vacutainers, $2-3 \mathrm{ml}$ porewater was drawn simultaneously from all depth intervals, which accounts for approx. 20-30\% of the total porewater volume in a $1 \mathrm{~cm}$ thick sediment layer (core diameter $5.4 \mathrm{~cm}$, porosity $\sim 0.4$ ). Although this principle worked well to obtain undisturbed samples for porewater analyses, sometimes, needles were clogged and porewater profiles were incomplete.

The gained porewater was subsampled for the analyses of sulfate and ammonium concentrations. For sulfate concentration, one $\mathrm{ml}$ porewater was transferred into one $\mathrm{ml}$ zinc acetate $(5 \% w / w)$. Porewater sulfate concentrations were measured using nonsuppressed ion chromatography with an au- tosampler (Spark Holland Basic and Marathon, injection volume $50 \mu \mathrm{l}$ ), an anion exchange column (LCA A14, Sykam) and a conductivity detector (S3110, Sykam). Ammonium concentrations in the porewater were determined via conductivity by the flow-injection method for small sample volumes developed by Hall and Aller (1992).

\subsection{Rate measurements}

Sediments for radiotracer incubation experiments were sampled with small core liners (i.d. $2.5 \mathrm{~cm}$ ). At each distance along the transects (April, November) and at each vent (June) two to four replicates were taken for methane oxidation and sulfate reduction measurements, respectively. Radioactive tracers (aliquots of $1.5 \mathrm{kBq}^{14} \mathrm{CH}_{4}$ dissolved in $15 \mu \mathrm{l}$ water for methane oxidation as well as $200 \mathrm{KBq}^{35} \mathrm{SO}_{4}$ dissolved in $6 \mu \mathrm{l}$ water for sulfate reduction) were injected into the cores in 1-cm-intervals according to the whole-core injection method (Jørgensen, 1978). The cores were incubated at $10^{\circ} \mathrm{C}$ for $24 \mathrm{~h}$ in the dark. After incubation, reactions were terminated by fixing $1 \mathrm{~cm}$-sections in $2.5 \%$ sodium hydroxide (methane oxidation) or $20 \%$ zinc acetate (sulfate reduction), respectively. In control samples activity was terminated before tracer addition. Methane oxidation rates were determined by gas chromatography, ${ }^{14} \mathrm{CH}_{4}$ combustion and ${ }^{14} \mathrm{CO}_{2}$ acidification as described in detail by Treude et al. (2005b). Sulfate reduction rates were determined according to the cold-chromium distillation method described by Kallmeyer et al. (2004).

\subsection{Identification of anaerobic methane-oxidizing (ANME) organisms by fluorescence in situ hybridization (FISH)}

Fixed samples were diluted (1:10) with PBS and treated by mild sonication for $20 \mathrm{~s}$ with a Branson probe (rod: Model 102 , sonifier: Model 250) at an amplitude of $42 \mu \mathrm{m}<10 \mathrm{~W}$. An aliquot ( $40 \mu \mathrm{l}$ ) was filtered on $0.2 \mu \mathrm{m}$ GTTP polycarbonate filters (Millipore Isopore Membrane Filters). The filters were embedded in low gelling point agarose. Hybridization and staining with $4^{\prime}, 6^{\prime}$-diamidino-2-phenylindole (DAPI) was performed as described previously (Snaidr et al., 1997). Mean values of ANME cell aggregate numbers were calculated by using $\sim 70$ randomly chosen grids for each filter section, corresponding to 100-500 hybridized cells. ALEXA 488-monolabeled oligonucleotides were purchased from Integrated DNA Technologies IDT DNA, San Diego, California. Probes and formamide (FA) concentrations used in this study were as follows: ANME-1-350 targeting ANME1 (Boetius et al., 2000, 40\% FA), ANME-2-538 targeting ANME-2 (Treude et al., 2005a, 50\% FA), ANME-3-1249 targeting ANME-3 (Niemann et al., 2006, 20\% FA). To avoid background signals 10\% Blocking Reagent (Roche) was added to hybridization buffers $(20 \% \mathrm{vol} / \mathrm{vol})$. 


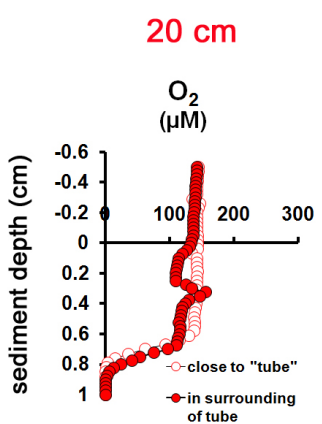

$200 \mathrm{~cm}$

$400 \mathrm{~cm}$

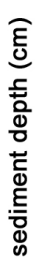
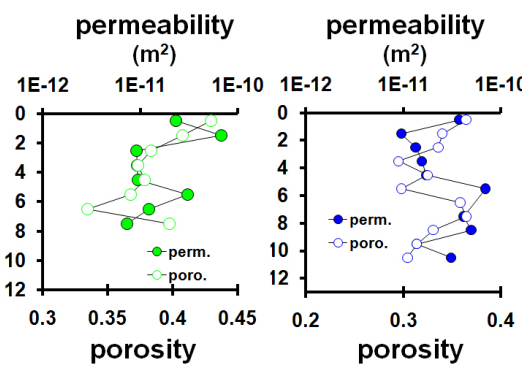

Fig. 1a. Biogeochemical profiles of the April sampling (transect) at Brian Seep: oxygen (2 replicates), permeability, and porosity. Samples were available from 20 (red), 200 (green), and $400 \mathrm{~cm}$ (blue) distance from the gas vent. The oxygen profiles were taken in the surrounding and close to a small tube, which could originate, e.g., from polychaetes living in the sediment.

\section{Results}

\subsection{April sampling, 0-400 cm transect}

Data sets were available only from 20-cm-April, 200-cmApril, and 400-cm-April (Fig. 1a-c). Sediment cores were not included for the analyses when there was any evidence of porewater leakage indicating mixing of porewater within the core. Leakage often resulted from larger sand grains that were caught between the rubber stoppers and core liners (see also missing parameters at 20-cm-April and 200-cm-April).

At 20-cm-April, oxygen penetration into the sediment was $8 \mathrm{~mm}$ in the vicinity of a small worm tube sticking out of the sediment. The oxygen profile was almost straight from the sediment-water interface down to $6 \mathrm{~mm}$, suggesting transport mechanisms other than diffusion, such as bioirrigation by biota (Fig. 1a, Jørgensen et al., 2005). Concentration in the overlying bottom water was $140 \mu \mathrm{M}$, i.e., lower than that at 400-cm-April ( $200 \mu$ M Fig. 1a), which could be explained by oxygen consumption during storage: the 20-cm-April core was profiled $\sim 1 \mathrm{~h}$ after the 400 -cm-April core. Oxygen penetration was therefore most likely reduced at the time of measurement. The methane profile (concentrations given per volume sediment) showed a subsurface maximum between 3 and $6 \mathrm{~cm}$ depth of max. $0.15 \mathrm{mM}$ (Fig. 1b), which roughly coincided with highest MOX rates (max. $82 \mathrm{nmol} \mathrm{cm}^{-3} \mathrm{~d}^{-2}$, Fig. 1b) and a peak in sulfide concentration (max. $2.7 \mathrm{mM}$,

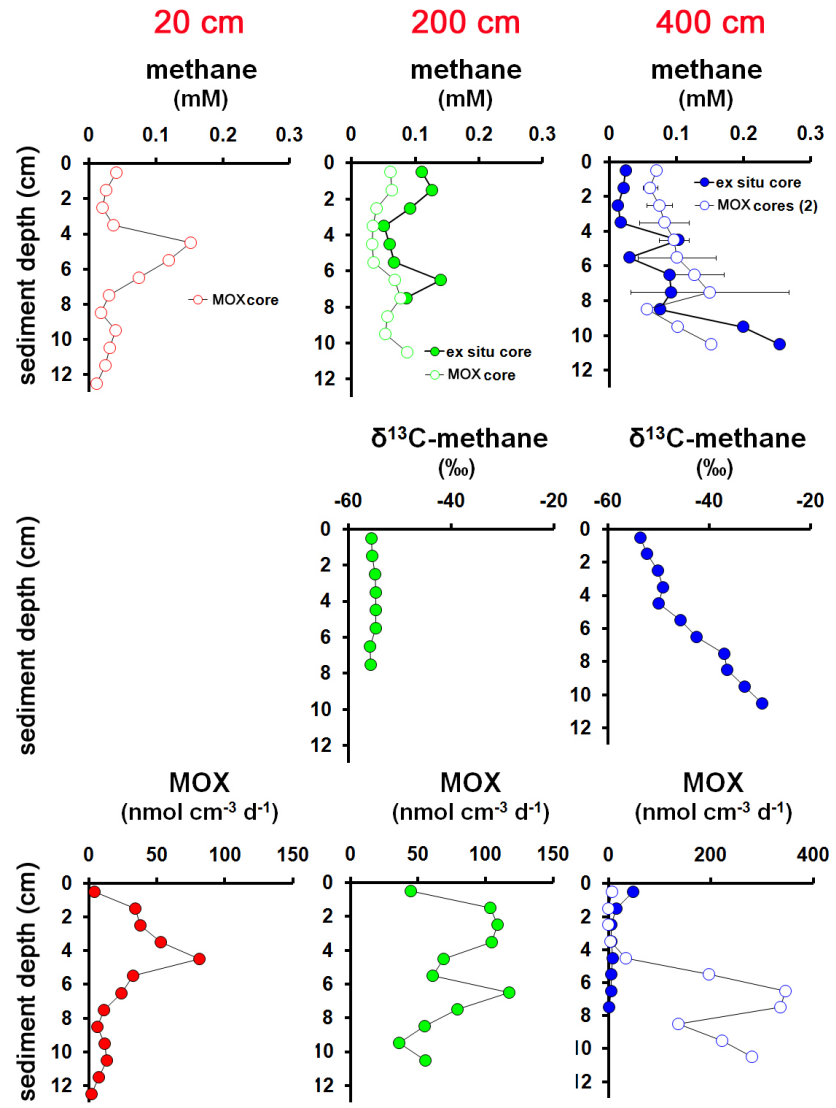

Fig. 1b. Biogeochemical profiles of the April sampling (transect) at Brian Seep: methane, $\delta^{13} \mathrm{C}$-methane, and methane oxidation (MOX, 2 replicates). Methane profiles show methane concentrations of samples taken immediately after recovery (ex-situ core) or after $24 \mathrm{~h}$ incubation (MOX cores, no. of replicates provided in legend, S.D. bars are given). Methane concentrations are presented in mmol L ${ }^{-1}$ sediment. Samples were available from 20 (red), 200 (green), and $400 \mathrm{~cm}$ (blue) distance from the gas vent.

Fig. 1c). Porewater sulfate concentrations at 20-cm-April did not change with depth remaining at a concentration of $\sim 27 \mathrm{mM}$ (Fig. 1c).

At $200-\mathrm{cm}$-April, porosity and permeability ranged between 0.34 and 0.43 as well as $7 \times 10^{-12}$ and $7 \times 10^{-11} \mathrm{~m}^{2}$, respectively, with no clear vertical trend (Fig. 1a). Methane concentrations and carbon isotopic values of methane also revealed no clear trend, fluctuating around $0.1 \mathrm{mM}$ (exsitu core) and $0.05 \mathrm{mM}$ (MOX core) of methane, and $-55 \%$ o $\delta^{13} \mathrm{C}$, respectively (Fig. 1b). Sulfate reduction (Fig. 1c) was between 10 and $50 \%$ of the measured MOX rates (Fig. 1b), i.e., $5-47 \mathrm{nmol} \mathrm{cm}^{-3} \mathrm{~d}^{-1}$ compared to $36-$ $118 \mathrm{nmol} \mathrm{cm}^{-3} \mathrm{~d}^{-1}$, respectively. Both activities were relatively evenly distributed over depth.

The 400-cm-April sample was much more stratified. Oxygen continuously decreased with depth to $0 \mu \mathrm{M}$ at $\sim 8 \mathrm{~mm}$ (Fig. 1a). Porosity and permeability data revealed no clear trend with depth showing values between 0.30 and 


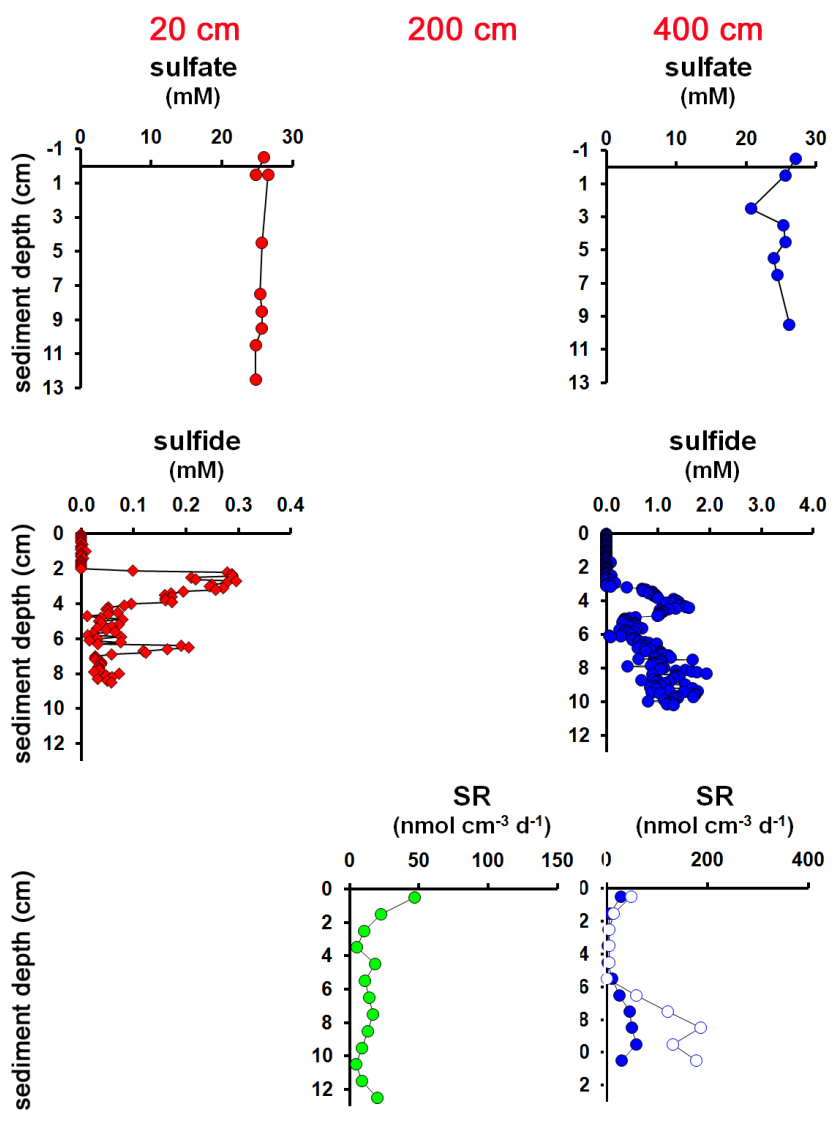

Fig. 1c. Biogeochemical profiles of the April sampling (transect) at Brian Seep: sulfate, sulfide, and sulfate reduction (SR, 2 replicates). Samples were available from 20 (red), 200 (green), and $400 \mathrm{~cm}$ (blue) distance from the gas vent.

0.36 as well as $9.6 \times 10^{-12}$ to $6.9 \times 10^{-11} \mathrm{~m}^{2}$, respectively (Fig. 1a). Methane concentrations were low in the upper $4 \mathrm{~cm}$ ( $\sim 0.02 \mathrm{mM}$ in ex-situ cores and $\sim 0.07 \mathrm{mM}$ in MOX cores) but increased with depth to max. concentrations of 0.15 and $0.25 \mathrm{mM}$, respectively (Fig. 1b). Carbon isotopic signatures of methane showed a nearly linear depletion of the lighter carbon isotope with depth (Fig. 1b). The increasingly heavier $\delta^{13} \mathrm{C}$ value $(-53.6 \%$ on top, $-29.5 \%$ at the bottom) of the porewater methane suggests microbial methane consumption in deeper sediment layers, due to preferential uptake of the lighter isotope by the microbes (Hinrichs et al., 1999). Correspondingly, MOX rates, which were low in the top $4 \mathrm{~cm}$, increased to max. $281 \mathrm{nmol} \mathrm{cm}^{-3} \mathrm{~d}^{-1}$ with depth (Fig. 1b), following the methane profile. Likewise, sulfide concentrations increased to $\sim 1.5 \mathrm{mM}$ (Fig. 1c), and sulfate reduction to max. $200 \mathrm{nmol} \mathrm{cm}^{-3} \mathrm{~d}^{-1}$ below $4 \mathrm{~cm}$ depth (Fig. 1c). Sulfate showed little change except for a very small subsurface decrease to $\sim 20 \mathrm{mM}$ at $3 \mathrm{~cm}$ (Fig. 1c).

In summary, methane concentrations per volume sediment were generally low over the entire transect, reaching max. values of only $0.25 \mathrm{mM}$. The methane concentrations were
Table 1. Areal rates of methane oxidation and sulfate reduction. Replicates were averaged $(n=2-4)$ and integrated over $10 \mathrm{~cm}$ sediment depth. n.d. $=$ not determined.

\begin{tabular}{lcc}
\hline & $\begin{array}{c}\text { Methan oxidation } \\
\mathrm{mmol} \mathrm{m}^{-2} \mathrm{~d}^{-1}\end{array}$ & $\begin{array}{c}\text { Sulfate reduction } \\
\mathrm{mmol} \mathrm{m}^{-2} \mathrm{~d}^{-1}\end{array}$ \\
\hline $\begin{array}{l}\text { April } \\
20 \mathrm{~cm}\end{array}$ & 2.97 & n.d. \\
$200 \mathrm{~cm}$ & 7.79 & 1.67 \\
$400 \mathrm{~cm}$ & 8.69 & 4.08 \\
June & & \\
Vent A & 1.28 & 2.30 \\
Vent B & 2.38 & 3.60 \\
November & & \\
$0 \mathrm{~cm}$ & 1.34 & 1.46 \\
$20 \mathrm{~cm}$ & 0.91 & 1.76 \\
$40 \mathrm{~cm}$ & 1.08 & 1.41 \\
$60 \mathrm{~cm}$ & 0.61 & 1.48 \\
\hline
\end{tabular}

below the expected saturation limits for the respective in-situ temperatures $\left(11-15^{\circ} \mathrm{C}\right)$, which ranged between 0.59 and $0.54 \mathrm{mM}$ at atmospheric pressure (Yamamoto et al., 1976) and between 1.13 and $1.23 \mathrm{mM}$ at in-situ pressure $(10 \mathrm{~m}$ depth; Duan and Mao, 2006) assuming an average porewater volume of $40 \%$ in the sediment. We found differences in the vertical distribution of microbial methanotrophy between different distances from the vent. Close to the venting center, there appeared to be a subsurface peak of activity around $4-5 \mathrm{~cm}$. At a distance of $200 \mathrm{~cm}$, activity was more or less evenly distributed over the core. At a distance of $400 \mathrm{~cm}$, most of the activity was located below $4 \mathrm{~cm}$ depth. Oxygen penetrated $8 \mathrm{~mm}$ into the sediment, hence, MOX activity at $0-1 \mathrm{~cm}$ sediment depth potentially could be attributed to aerobic methane oxidation, whereas MOX in deeper, anoxic layers $(\sim>2 \mathrm{~cm})$ was most likely anaerobic oxidation of methane (AOM). Sulfate reduction detected in $0-1 \mathrm{~cm}$ layers was probably coupled to organic matter degradation, rather than to AOM, because AOM organisms are strict anaerobes (Treude et al., 2005b), whereas some sulfate reducers can tolerate oxygen (Jørgensen, 1994). Deeper sediment layers could be mixtures of both, sulfate reduction coupled to organic matter degradation as well as AOM. Areal rates of MOX (including both aerobic and anaerobic processes) integrated over the top $10 \mathrm{~cm}$ sediment increased with distance from the vent to a max. of $8.69 \mathrm{mmol}^{-2} \mathrm{~d}^{-1}$ at $400-\mathrm{cm}$-April (Table 1). Areal rates of sulfate reduction were approximately half $\left(1.67\right.$ and $4.08 \mathrm{mmol}^{-2} \mathrm{~d}^{-1}$ at 20 and 400-cm-April, respectively) of the areal MOX (Table 1).

\subsection{November sampling, $0-60 \mathrm{~cm}$ transect}

At 0-cm-November, oxygen penetrated max. $4 \mathrm{~mm}$ (Fig. 2a). We found indications for oxygen production from photosynthesis just below the sediment surface, probably induced by 


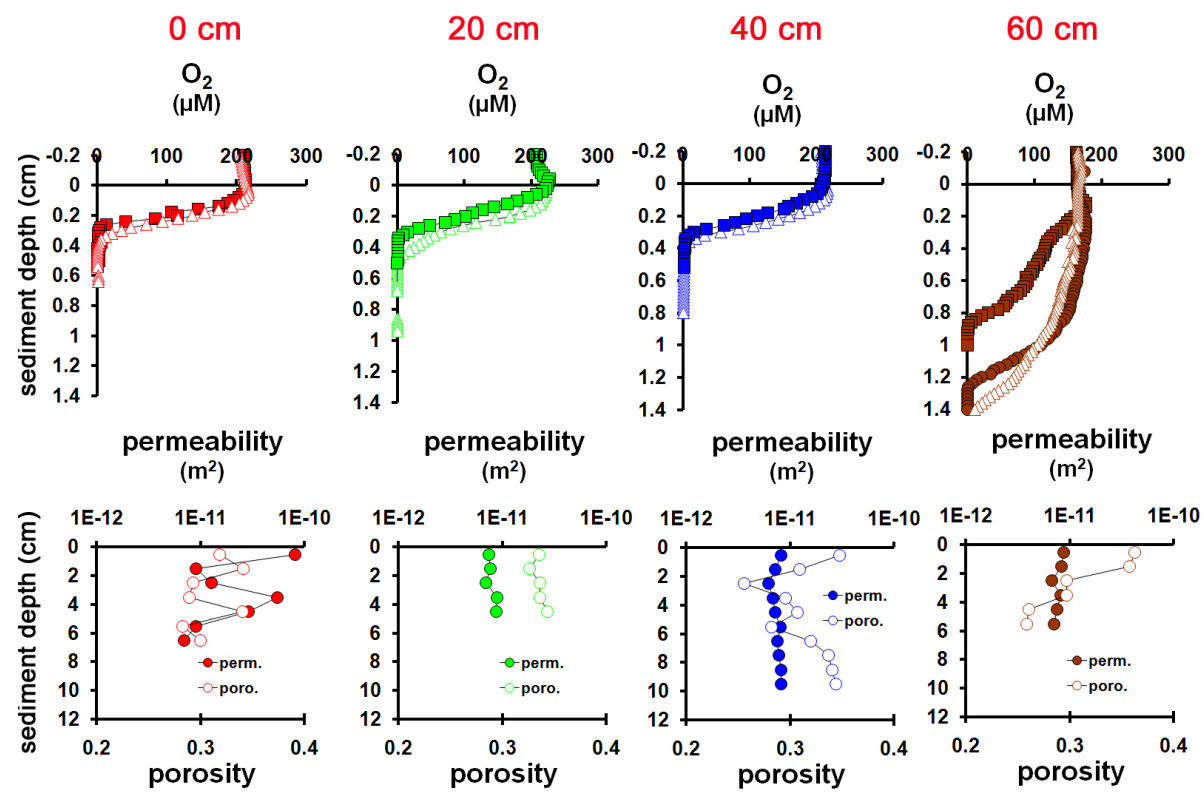

Fig. 2a. Biogeochemical profiles of the November sampling (transect) at Brian Seep: oxygen (2-3 replicates), permeability, and porosity. Distances from gas vent: 0 (red), 20 (green), 40 (blue), and $60 \mathrm{~cm}$ (brown).

light exposure during profiling. Below this activity, oxygen concentration decreased rapidly. Porosity and permeability revealed a zigzag profile with no clear trend ranging between 0.28 and 0.34 as well as $7 \times 10^{-12}$ and $8 \times 10^{-11} \mathrm{~m}^{2}$, respectively (Fig. 2a). Methane concentrations revealed similar pattern in ex-situ $(0-6 \mathrm{~cm})$ and MOX-cores $(0-9 \mathrm{~cm})$, with peaks $(\sim 0.2 \mathrm{mM})$ between 3 and $6 \mathrm{~cm}$ (Fig. $2 \mathrm{~b}$ ). Carbon isotopic signatures of methane $\left(\delta^{13} \mathrm{C}\right)$ increased almost linearly from -53 to $-39 \%$ between top and bottom $(7 \mathrm{~cm})$ of the core (Fig. 2b) indicating microbial methane consumption at depth. MOX rates were highest in the top $(0-1 \mathrm{~cm})$ layer reaching values between 60 and $70 \mathrm{nmol} \mathrm{cm}^{-3} \mathrm{~d}^{-1}$ in replicates (Fig. 2b). Rates decreased with depth $(\max .9 \mathrm{~cm})$ to levels between 1 and $5 \mathrm{nmol} \mathrm{cm}^{-3} \mathrm{~d}^{-1}$ with the exception of one deeper peak $\left(37 \mathrm{nmol} \mathrm{cm}^{-3} \mathrm{~d}^{-1}\right)$ at $4-5 \mathrm{~cm}$ in one replicate. Sulfate was measured only until a depth of $5 \mathrm{~cm}$ and remained constant around $28 \mathrm{mM}$ (Fig. 2c). Sulfate reduction rates were relatively stable with only a small peak (15$30 \mathrm{nmol} \mathrm{cm}^{-3} \mathrm{~d}^{-1}$ ) at the surface and a slight decrease towards the bottom (Fig. 2c). Below $10 \mathrm{~cm}$, rates decreased to values $\sim 1 \mathrm{nmol} \mathrm{cm}^{-3} \mathrm{~d}^{-1}$. Ammonium concentrations were measured only up to a max. depth of $5 \mathrm{~cm}$ and remained below $<8 \mu \mathrm{M}$ (Fig. 2c).

At 20-cm-November, oxygen penetrated max. $4 \mathrm{~mm}$ (Fig. 2a) with a similar profile as 0 -cm-November. Porosity and permeability remained relatively stable around 0.34 and $7 \times 10^{-12}$, respectively, over the core $(0-5 \mathrm{~cm}$, Fig. $2 \mathrm{a})$. Methane concentrations remained very low $(<0.05 \mathrm{mM})$ in the ex-situ core (max. depth $5 \mathrm{~cm}$ ) but revealed increasing values with depth in the MOX-cores reaching on average $0.17 \mathrm{mM}$ at $8 \mathrm{~cm}$ (Fig. 2b). Carbon isotopic signa- tures of methane $\left(\delta^{13} \mathrm{C}\right)$ were around $-45 \%$ at top and bottom $(5 \mathrm{~cm})$, with an intermediate minimum of $-55 \%$ at $2-$ $3 \mathrm{~cm}$ (Fig. 2b). MOX rates were highest in the top $(0-1 \mathrm{~cm})$ layer reaching values around $35 \mathrm{nmol} \mathrm{cm}^{-3} \mathrm{~d}^{-1}$ (Fig. 2b) and decreased with depth $(\max .8 \mathrm{~cm})$ to levels between 3 and $10 \mathrm{nmol} \mathrm{cm}^{-3} \mathrm{~d}^{-1}$. Sulfate remained stable around $28 \mathrm{mM}$ in the top $10 \mathrm{~cm}$ (Fig. 2c). The two sulfate reduction replicates revealed opposite trends, i.e. rates either decreased or increased with depth (Fig. 2c). Both replicates featured sulfate turnover around $20 \mathrm{nmol} \mathrm{cm}^{-3} \mathrm{~d}^{-1}$ at the surface. A max. of $60 \mathrm{nmol} \mathrm{cm} \mathrm{c}^{-3} \mathrm{~d}^{-1}$ was reached in one replicate at $6-7 \mathrm{~cm}$. Ammonium concentrations steadily increased from seawater concentrations $(2 \mu \mathrm{M})$ at the top to max values $\sim 40 \mu \mathrm{M}$ between 8 and $11 \mathrm{~cm}$ (Fig. 2c).

At 40-cm-November, oxygen penetrated max. $4 \mathrm{~mm}$ (Fig. 2a) with a similar profile as $0-$ and $20-\mathrm{cm}$-November. Permeability remained relatively stable around $8 \times 10^{-12}$, over the entire core $(0-10 \mathrm{~cm}$, Fig. 2a). Porosity revealed some variability with depth: at top and bottom values were around 0.34; between 2 and $7 \mathrm{~cm}$ depth, values decreases to a minimum of 0.26 (Fig. 2a). Methane concentrations remained very low $(<0.1 \mathrm{mM})$ in both ex-situ and MOX cores in the top $8 \mathrm{~cm}$ (Fig. 2b). At 9-10 cm, concentrations increased to $1 \mathrm{mM}$ in the ex-situ core. Carbon isotopic signatures of methane $\left(\delta^{13} \mathrm{C}\right)$ were around $-55 \%$ o between 0 and $4 \mathrm{~cm}$, then increased to $-38 \%$ ontil $9 \mathrm{~cm}$, indicating microbial methane consumption in deeper layers; in the 9-10 cm layer the value decreased again to $-50 \%$ (Fig. $2 b$ ). MOX rates were highest in the top $(0-1 \mathrm{~cm})$ layer reaching values between 20 and $100 \mathrm{nmol} \mathrm{cm}^{-3} \mathrm{~d}^{-1}$ in replicates (Fig. 2b) and decreased with depth $(\max .9 \mathrm{~cm})$ to levels between 1 and 


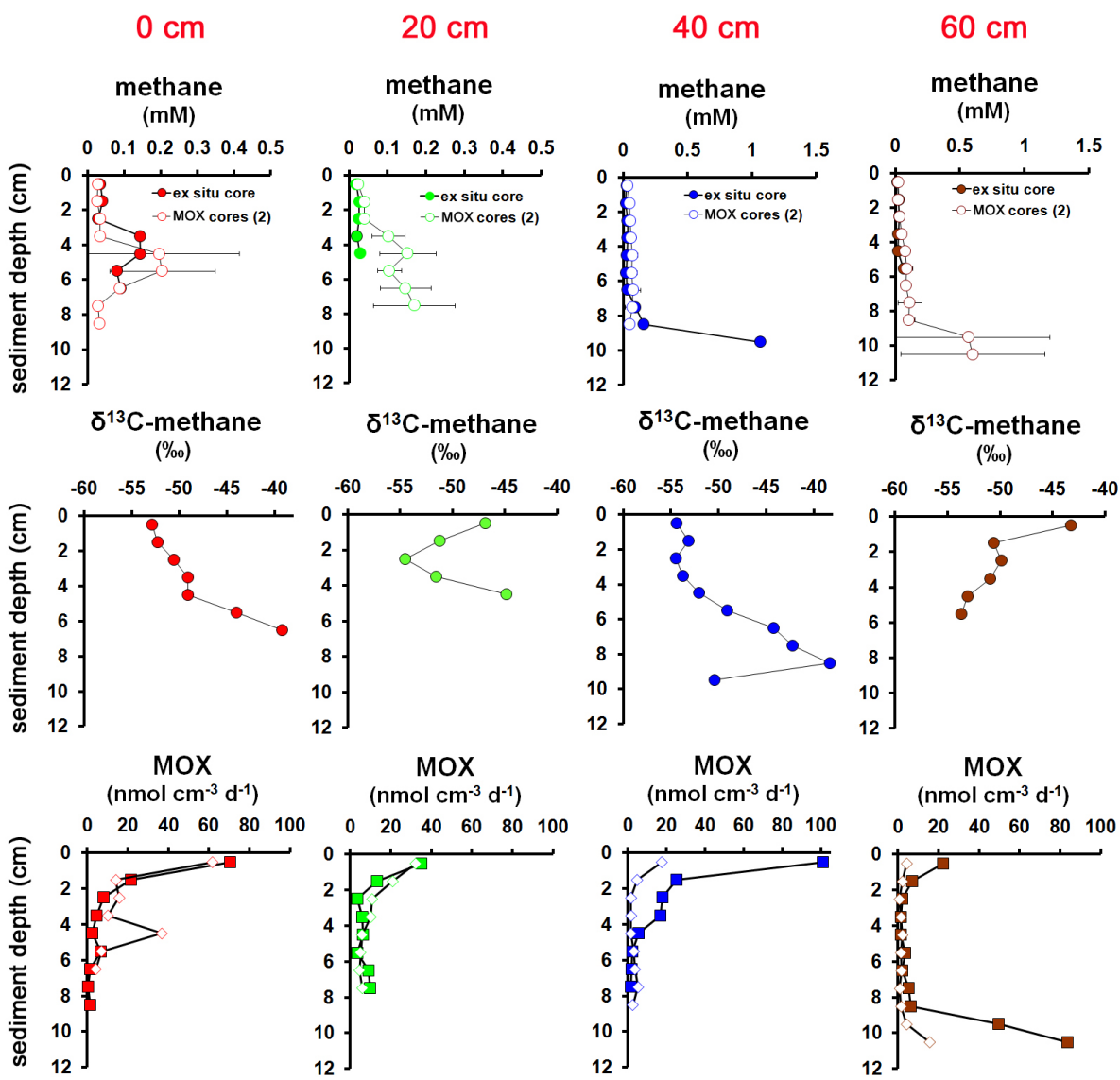

Fig. 2b. Biogeochemical profiles of the November sampling (transect) at Brian Seep: methane, $\delta^{13} \mathrm{C}$-methane, and methane oxidation (MOX, 2 replicates). Methane profiles show methane concentrations of samples taken immediately after recovery (ex-situ core) or after $24 \mathrm{~h}$ incubation (MOX cores, no. of replicates provided in legend, S.D. bars are given). Methane concentrations are presented in mmol $\mathrm{L}^{-1}$ sediment. Distances from gas vent: 0 (red), 20 (green), 40 (blue), and $60 \mathrm{~cm}$ (brown).

$5 \mathrm{nmol} \mathrm{cm} \mathrm{c}^{-3} \mathrm{~d}^{-1}$. Sulfate remained stable around $28 \mathrm{mM}$ in the top $11 \mathrm{~cm}$ (Fig. 2c). Sulfate reduction fluctuated between 10 and $40 \mathrm{nmol} \mathrm{cm} \mathrm{d}^{-1}$ in the top $8 \mathrm{~cm}$ of the replicates and decreased to $<8 \mathrm{nmol} \mathrm{cm}^{-3} \mathrm{~d}^{-1}$ beneath (Fig. 2c). Ammonium concentrations increased linearly from seawater concentrations $(2 \mu \mathrm{M})$ at the top to $12 \mu \mathrm{M}$ at $9-10 \mathrm{~cm}$ (Fig. 2c). In the $10-11 \mathrm{~cm}$ layer, concentrations increased to $32 \mu \mathrm{M}$.

At $60-\mathrm{cm}$-November, oxygen penetrated to maxima of 8 $14 \mathrm{~mm}$, in slightly concave profiles (Fig. 2a). The profile indicated that other processes than diffusion might be responsible for oxygen transport. Permeability remained stable around $8 \times 10^{-12}$, over the entire the core $(0-6 \mathrm{~cm}$, Fig. $2 \mathrm{a})$. Porosity decreased from 0.36 at the top to 0.26 at the bottom (Fig. 2a). Similar to 40-cm-November, methane concentrations remained generally very low $(\leq 0.1 \mathrm{mM})$ in the top $9 \mathrm{~cm}$ and increased to average values of $\sim 0.6 \mathrm{mM}$ in the $9-11 \mathrm{~cm}$ layer (Fig. 2b). Carbon isotopic signatures of methane $\left(\delta^{13} \mathrm{C}\right)$ decreased from $-43 \%$ at the top to $-54 \%$ o at the bottom $(6 \mathrm{~cm}$, Fig. $2 \mathrm{~b})$, indicating methane oxidation at the top. MOX rates revealed a small peak at the top $\left(22 \mathrm{nmol} \mathrm{cm}{ }^{-3} \mathrm{~d}^{-1}\right)$, remained low between 2 and $9 \mathrm{~cm}$ $\left(<7 \mathrm{nmol} \mathrm{cm}^{-3} \mathrm{~d}^{-1}\right)$, and in one replicate increased again up to $83 \mathrm{nmol} \mathrm{cm}^{-3} \mathrm{~d}^{-1}$ beneath (Fig. $2 \mathrm{~b}$ ). The sulfate profile was incomplete, but concentration did not change $(\sim 28 \mathrm{mM})$ in all measured depths up to $11-12 \mathrm{~cm}$ (Fig. 2c). Similar to 40-cm-November, sulfate reduction rates fluctuated over the core with values between 1 and $35 \mathrm{nmol} \mathrm{cm}^{-3} \mathrm{~d}^{-1}$ (Fig. 2c). Ammonium concentrations increased from seawater concentrations $(2 \mu \mathrm{M})$ at the top to $8 \mu \mathrm{M}$ at $9-10 \mathrm{~cm}$ (Fig. $2 \mathrm{c})$. In the $11-12 \mathrm{~cm}$ layer, concentrations increased to $21 \mu \mathrm{M}$.

In summary, oxygen revealed a similar penetration depths of $\sim 4 \mathrm{~mm}$ along the transect, except for the $60 \mathrm{~cm}$ distance, where oxygen had a 2-3 times higher penetration. Two explanations could be an inflow of oxygen-rich bottom water at the outer recharge zone $(60 \mathrm{~cm}$ distance) of the seep and/or the higher aerobic methane consumption rates in the vicinity of the gas vent $(0-40 \mathrm{~cm}$ distance). Methane concentrations remained generally low in the surface sediment (see above). Maxima of methane consumption (except for the $9-11 \mathrm{~cm}$ layer at $60-\mathrm{cm}-$ November) were detected mainly at the surface $(0-1 \mathrm{~cm})$, where it was most likely coupled to aerobic oxidation of methane (see above). Increases of ammonium 

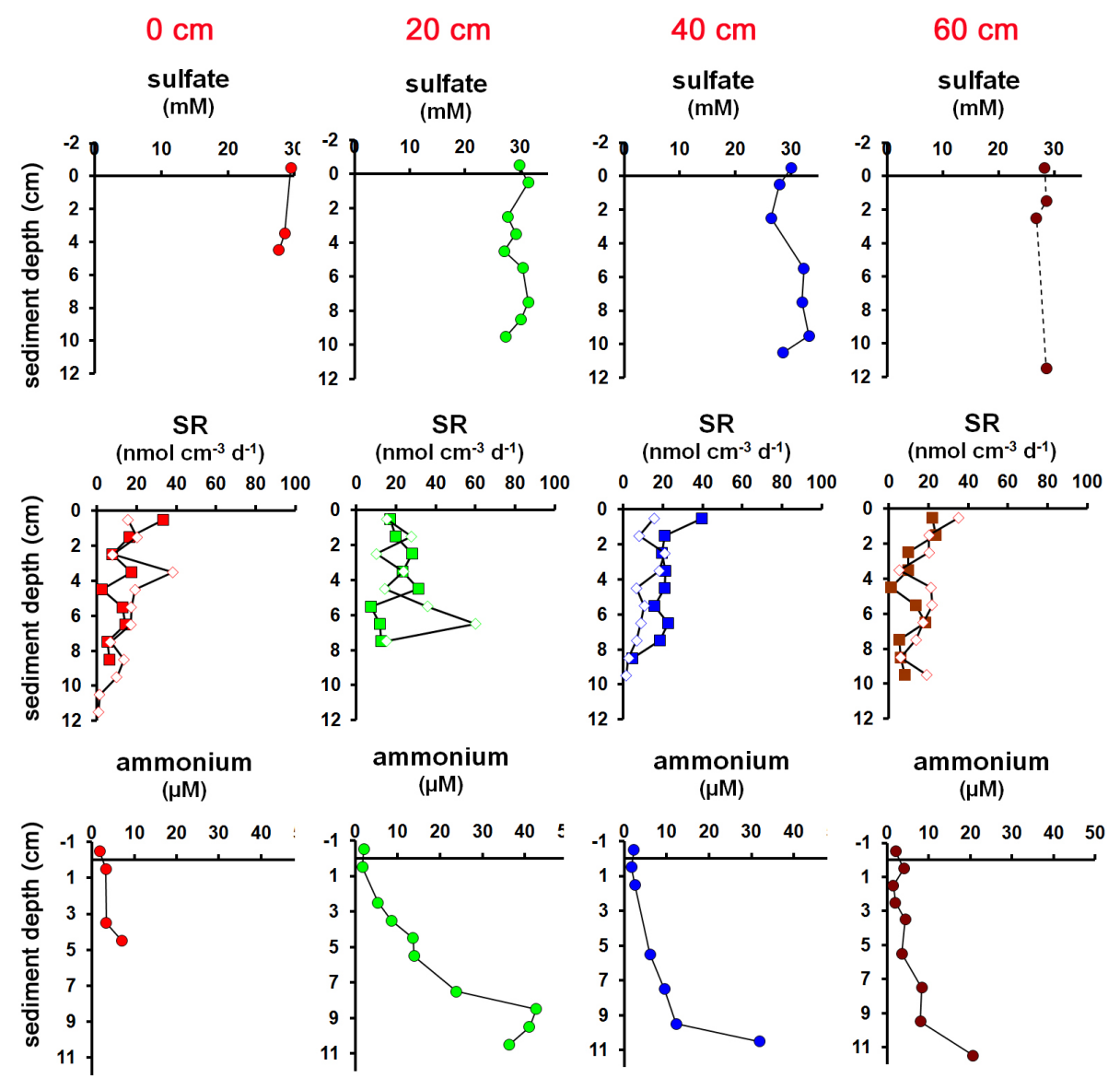

Fig. 2c. Biogeochemical profiles of the November sampling (transect) at Brian Seep: sulfate, sulfate reduction (SR, 2 replicates), and ammonium. At $60 \mathrm{~cm}$, the sulfate profile is dashed, because of low reliability given by the limited amount of data points over depth. Distances from gas vent: 0 (red), 20 (green), 40 (blue), and $60 \mathrm{~cm}$ (brown).

concentrations with depth point to slightly more reduced conditions in deeper sediment layers. Within the profiled depths $(0-6 \mathrm{~cm})$ no sulfide was detected. Profiles of methane concentration and $\delta^{13} \mathrm{C}$-values point to anaerobic oxidation of methane in deeper layers of the sediments. The majority of sulfate reduction did not seem to be coupled to AOM but rather to organic matter degradation.

\subsection{June sampling, Vent A and B}

At Vent A, oxygen penetrated $2.2 \mathrm{~mm}$, with a bottom water concentration of $200 \mu \mathrm{M}$ (Fig. 3a) compared to only $160 \mu \mathrm{M}$ at Vent B (Fig. 3a). Here again, the lower concentration at Vent B might be explained by the processing order (see above). Porosity and permeability remained relatively stable at 0.4 and $10^{-11} \mathrm{~m}^{2}$, respectively (Fig. 3a). Ammonium concentrations fluctuated slightly but overall increased with depth to max. values of 15-20 $\mu \mathrm{M}$ (Fig. 3a). Methane concentrations slightly increased with depth in ex-situ cores (max. $0.28 \mathrm{mM}$, Fig. 3b). The trend was less pronounced in MOX cores (values $\sim 0.1 \mathrm{mM}$, Fig. $3 \mathrm{~b}$ ). Methane isotopic signatures showed depletion of the lighter carbon isotope with depth $\left(\delta^{13} \mathrm{C}\right.$ value $-55.5 \%$ on top and $-41.1 \%$ at the bottom, Fig. 3b), pointing to methane oxidation at depth. In contrast, MOX rates (measured to a max. depth of $14 \mathrm{~cm}$ ) revealed highest activity $\left(45 \mathrm{nmol} \mathrm{cm}{ }^{-3} \mathrm{~d}^{-1}\right)$ mainly at the surface and decreased to values $<5 \mathrm{nmol} \mathrm{cm}^{-3} \mathrm{~d}^{-1}$ below $4 \mathrm{~cm}$ depth (Fig. 3b). Sulfate concentrations showed only little change with depth, still reaching values of $24 \mathrm{mM}$ at $10 \mathrm{~cm}$ (Fig. 3b). No sulfide was detected in the measured depths $(0-6 \mathrm{~cm}$, Fig. 3b). Sulfate reduction was in the range between $4-80 \mathrm{nmol} \mathrm{cm}^{-3} \mathrm{~d}^{-1}$ with no consistent trends down core (Fig. 3b).

At Vent B, oxygen penetrated $1.4 \mathrm{~mm}$ (Fig. 3a). Porosity and permeability values were similar to Vent A (see above, Fig. 3a). Ammonium profiles were incomplete due to problems with the porewater extraction and trends were difficult to identify. Generally, lower concentrations $(3-7 \mu \mathrm{M})$ were observed at the sediment-water interface, compared to depth (18 and $51 \mu \mathrm{M}$ at $4-5$ and 6-7 cm, respectively, Fig. 3a). In methane samples taken immediately after core retrieval (exsitu) concentrations were up to 4 times higher compared to 


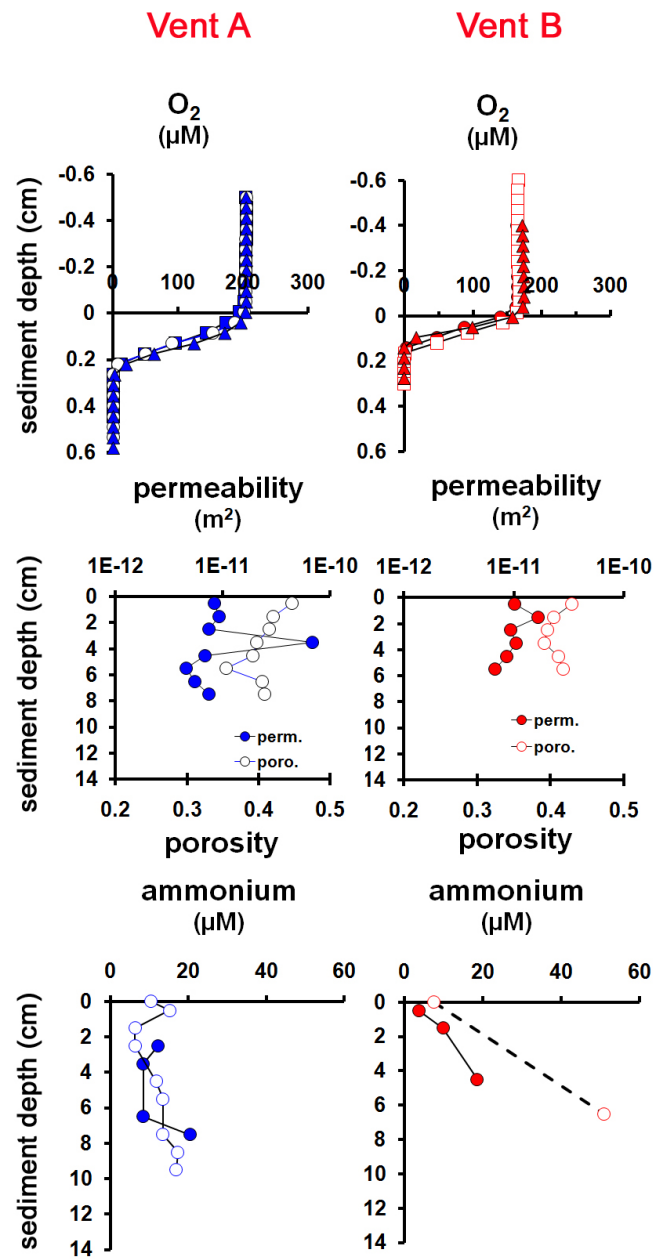

Fig. 3a. Biogeochemical profiles of the June sampling at Brian Seep: oxygen (3 replicates), permeability, porosity, and ammonium. At $60 \mathrm{~cm}$, the ammonium profile is dashed, because of low reliability given by the limited amount of data points over depth. Cores were sampled close to gas vents: Vent A (blue) and B (red).

MOX cores (measured $24 \mathrm{~h}$ after incubation, Fig. 3b). Differences could be attributed either to sediment heterogeneity or microbial depletion of methane during incubation. In the ex-situ core, concentrations increased with depth to max values of $0.42 \mathrm{mM}$ at $4-5 \mathrm{~cm}$. $\delta^{13} \mathrm{C}$-values of methane fluctuating around $-40 \%$ in the top $5 \mathrm{~cm}$ (Fig. 3b). MOX and sulfate reduction rates basically revealed the same profile as Vent $\mathrm{A}$ besides that in one of each replicates a single max. of $126 \mathrm{nmol} \mathrm{cm}^{-3} \mathrm{~d}^{-1}(5-6 \mathrm{~cm})$ and $352 \mathrm{nmol} \mathrm{cm}^{-3} \mathrm{~d}^{-1}(6-$ $7 \mathrm{~cm}$ ) was found, respectively, pointing to elevated AOM activity (Fig. 3b). The two peaks were in good agreement with high sulfide levels $\sim 2.2 \mathrm{mM}$ detected between 6.2 and $8 \mathrm{~cm}$ (Fig. 3b). Porewater sulfate profiles were incomplete; however, values still reached $25 \mathrm{mM}$ at $7 \mathrm{~cm}$ depth (Fig. 3b).

In summary, sediments taken in the vicinity of focused gas vents were dominated by subsurface activity of MOX, which, however, did not result in a depletion of sulfate.
Areal MOX rates integrated over $10 \mathrm{~cm}$ depth were 1.28 and $2.38 \mathrm{mmol} \mathrm{m}^{-2} \mathrm{~d}^{-1}$ for Vent A and Vent B, respectively (Table 1). Areal sulfate reduction rates integrated over $10 \mathrm{~cm}$ depth were 2.30 and $3.60 \mathrm{mmol} \mathrm{m}^{-2} \mathrm{~d}^{-1}$, respectively (Table 1), i.e., by a factor of 1.8 and 1.5 higher than integrated MOX rates, respectively.

\subsection{Fluorescence in situ hybridization of ANME organisms}

By using fluorescently labeled oligonucleotide probes targeting specificically the ANME-1, -2 , or -3 , groups, only the ANME- 2 probes revealed positive labeling results. Small cell aggregates of ANME-2 were found in selected samples of the 400-cm-April sediment (Fig. 4a, c). DAPI counterstaining, revealed a higher amount of total cells (Fig. 4b, d), suggesting that the aggregates also contained cells other than ANME-2. Aggregates were not found in the top $0-2 \mathrm{~cm}$ of the cores (Fig. 4e). Deeper samples revealed abundances of 2.3 and $7.3 \times 10^{6}$ aggregates $\mathrm{cm}^{-3}$ sediment at 6-7 and 8$9 \mathrm{~cm}$, respectively. Assuming that both the aggregates and cells had a spherical shape with an average diameter of 2 and $0.5 \mu \mathrm{m}$, respectively, and assuming a face centered cubic or hexagonal packing of the cells inside the aggregates (packing density $=0.7405$ ), aggregates had an average number of 63 cells (volume aggregate/volume cell $\times$ packing density). Accordingly, total cell numbers (including ANME-2 and additional cells in the aggregates) were approximately 1.5 and $4.6 \times 10^{8}$ cells $\mathrm{cm}^{-3}$ sediment at 6-7 and 8-9 $\mathrm{cm}$ depth, respectively.

\section{Discussion}

The shallow ( $\sim 10 \mathrm{~m})$ Brian Seep area off Coal Oil Point is characterized by a $15-20 \mathrm{~cm}$ thick sediment cover, which consists of well-sorted sand featuring low porosity (0.26$0.45)$ and high permeability $\left(\sim 10^{-11} \mathrm{~m}^{2}\right)$. Sandy seabeds are typical for such shallow-water environments, where wave and tidal action lead to a resuspension of the upper sediment layers. High sediment permeability facilitates fluid transport through the sediment matrix and allows advective processes (Huettel et al., 1998). It has been documented that pressure gradients at the sediment-water interface are driving forces for porewater advection, which rapidly transport fluids and particles into layers much deeper and faster compared to diffusive transport (Precht et al., 2004; Huettel et al., 2003; Huettel et al., 1998; Ziebis et al., 1996). When combined with gas venting, as it occurs in the Brian Seep area, convection of porewater can be induced (Dando et al., 1994a; O'Hara et al., 1995). The rising gas is entraining porewater from the surrounding sediment, leading to a fast removal of reduced compounds. This fluid discharge into the hydrosphere has to be replaced by water flowing into the sediment in a "recharge zone", allowing a deeper penetration of 


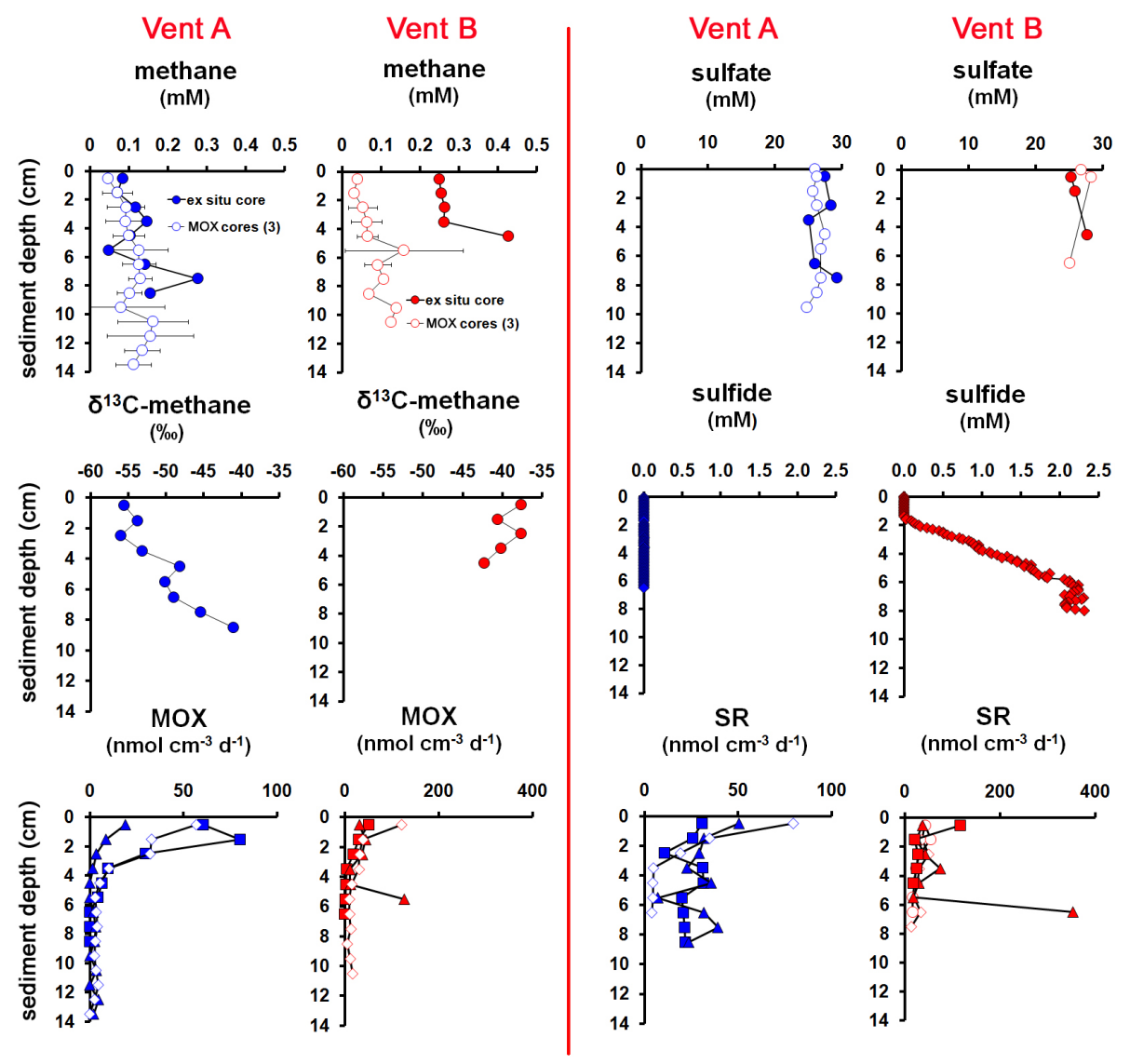

Fig. 3b. Biogeochemical profiles of the June sampling at Brian Seep: methane, $\delta^{13} \mathrm{C}$-methane, methane oxidation ( 3 replicates), sulfate, sulfide, and sulfate reduction (3-4 replicates). Methane profiles show methane concentrations of samples taken immediately after recovery (ex-situ core) or after $24 \mathrm{~h}$ incubation (MOX cores, no. of replicates provided in legend). Methane concentrations are presented in mmol $\mathrm{L}^{-1}$ sediment. Cores were sampled close to gas vents: Vent A (blue) and B (red).

oxidants from the overlying water. Gas ebullition can also strip other gases such as $\mathrm{H}_{2} \mathrm{~S}$ from the porewater (O'Hara et al., 1995).

In the present study, we measured a variety of biogeochemical parameters in the sandy surface sediment $(0$ $15 \mathrm{~cm}$ ) of Brian Seep around sites of focused gas venting. Our primary goal was to investigate how the venting affects microbial methanotrophy and geochemical gradients within the permeable seabed. We also aimed at comparing and contrasting our results to methane seep environments found in deeper benthic zones (Table 2).

It should be noted that ex-situ measurements of samples taken from such a dynamic environment are very challenging. The natural geochemical profiles can be altered during core sampling (hammering, sealing) and transportation. Especially under the stagnant conditions after sampling, chemical parameters may have changed rapidly. In the case of oxygen, this could have resulted in an underestimation of the actual in-situ concentration and penetration depth (Berg et al., 2003), as well as of the aerobic methane oxidation rates. Furthermore, gases such as methane could be partly lost during core sectioning. However, in order to compare geochemical parameters with microbial turnover rates, which can hardly be gained in-situ, we used the same sampling technique for all cores and processed them as fast as possible after retrieval. We are confident that the data still provide valuable information about general biogeochemical features in sandy seeps. Nevertheless, the data do not reflect the actual in-situ conditions of the seep.

Despite stagnant conditions during micro-profiling, we observed a relatively deep oxygen penetration of up to $14 \mathrm{~mm}$ at Brian Seep, when compared to methane seeps with finegrained sediments (Table 2). The deeper penetration could be explained by advective transport processes through permeable sand (e.g., Huettel and Gust, 1992; Huettel et al., 1998). Alternatively, it might indicate recharge processes for the convective pore water transport, which is induced by the gas and fluid venting (Dando et al., 1994a). Deep oxygen penetration offers a niche for aerobic methanotrophs in the surface sediments of Brian Seep. Although methane turnover rate measurements using ${ }^{14} \mathrm{C}$-labeled methane do not decipher which electron acceptor is responsible for methane 
Table 2. Comparison of biogeochemical parameters between Bryan Seep (shallow sandy sediment) and deep-sea seeps (fine-grained muddy sediments). Considered are sites revealing the highest AOM rates and not containing major bioturbation/bioirrigation activity of clams or annelid worms. PD=penetration depth; $\mathrm{mM} @ \mathrm{~cm}=$ concentration measured at max sampling depth or where sulfate reached zero; Max $[\mathrm{CH} 4]=$ maximum methane concentration measured in the top $15 \mathrm{~cm}$ of the sediment at atmospheric pressure; Max $\left[\mathrm{H}_{2} \mathrm{~S}\right]=\operatorname{maximum}$ sulfide concentration measured in the top $15 \mathrm{~cm}$ of the sediment; MOX = methane oxidation (aerobic and anaerobic) integrated over $10 \mathrm{~cm}$ sediment depth; n.d. = not determined. Sources: 1 = Boetius \& Suess 2004, Sahling et al., 2002, Sommer et al., 2006, Treude et al., 2003b, 2 = Joye et al., 2004, Orcutt et al., 2005, Orcutt et al., 2008; 3 = Niemann \& Loesekann et al., 2006, Soltwedel et al., 2005.

\begin{tabular}{|c|c|c|c|c|c|c|c|c|}
\hline Cold Seep & $\begin{array}{l}\text { Sediment } \\
\text { type }\end{array}$ & Porosity & $\begin{array}{l}\text { Oxygen PD } \\
(\mathrm{cm})\end{array}$ & $\begin{array}{l}\text { Sulfate PD } \\
(\mathrm{mM} \text { at respective } \\
\text { depth in } \mathrm{cm})\end{array}$ & $\begin{array}{l}\operatorname{Max}\left[\mathrm{CH}_{4}\right] \\
(\mathrm{mM})\end{array}$ & $\begin{array}{l}\operatorname{Max}\left[\mathrm{H}_{2} \mathrm{~S}\right] \\
(\mathrm{mM})\end{array}$ & $\begin{array}{l}\text { MOX rate } \\
\left(\mathrm{mmol} \mathrm{m}^{2} \mathrm{~d}^{-1}\right)\end{array}$ & Sources \\
\hline Bryan Seep & sand & $0.26-0.45$ & $0.2-1.4$ & 25@13 & $0.14-1.06$ & $0-2$ & $0.6-8.7$ & this study \\
\hline Hydrate Ridge & fine-grained mud & $0.62-0.73$ & $0.0-0.7$ & $2 @ 10$ & $1.0-4.2$ & $10-26$ & 99 & 1 \\
\hline Gulf of Mexico & fine-grained mud & 0.6 & n.d. & 1-5@10 & $1.4-7.0$ & $10-20$ & $2.6-4.6$ & 2 \\
\hline Håkon Mosby Mud Volcano & fine-grained mud & $0.43-0.64$ & $0.1-0.2$ & $0 @ 4-6$ & n.d. & 5 & 4.5 & 3 \\
\hline
\end{tabular}

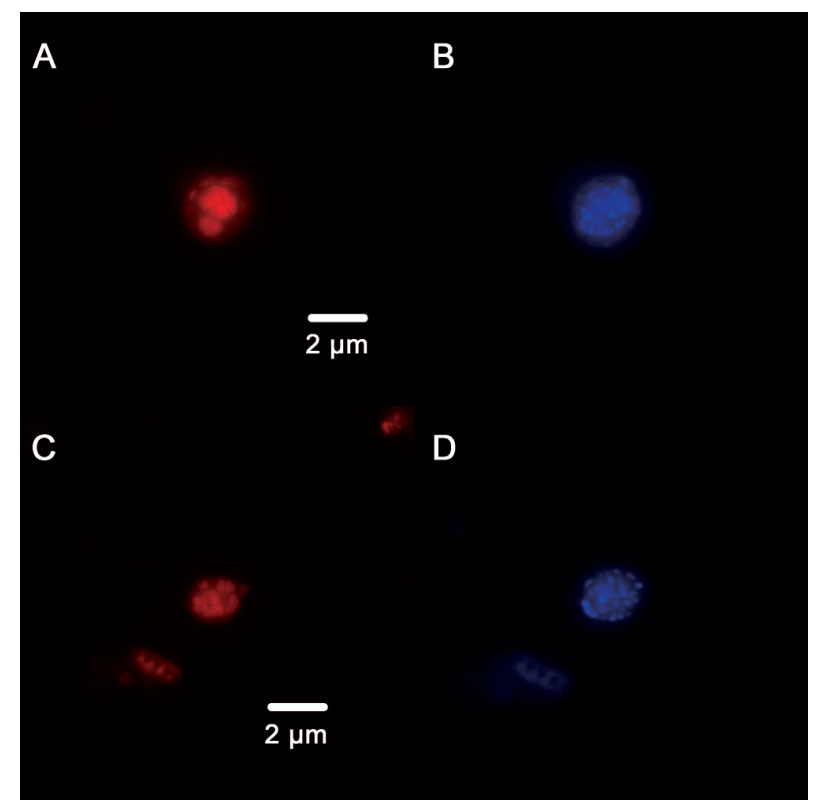

Fig. 4. (A, C) In situ identification of ANME-2 aggregates with fluorescently labeled rRNA-targeted oligonucleotide probes (ALEXA 488-labeled). (B, D) DAPI counter staining. A scale bar is provided.

oxidation, pronounced methane turnover in the $0-1 \mathrm{~cm}$ layer of many sediment cores (Figs. 1b, 2b, and 3b) suggests that aerobic, rather than anaerobic, methanotrophy is taking place within this interface layer. Under in-situ conditions the oxygenated habitat might spread into even deeper layers, depending on the extent of convective transport (Dando et al., 1994a). Correspondingly, cells belonging to the anaerobic methanotroph (ANME) clusters were not detected in the top two centimeters. ANME communities might be excluded from this dynamic periphery and only increase in abundance in deeper sediment layers, due to their oxygen sensitivity (Treude et al., 2005b).
According to the concept of gas-driven convection cells in permeable sediments, we would expect shallow peaks of methanotrophy in the vicinity of a venting point, whereas more distant locations should reveal deeper activity (Dando et al., 1994a; O'Hara et al., 1995). Although methane oxidation in our study featured some vertical variability, a significant trend was difficult to extrapolate from the small amounts of measurements conducted. This observation confirms again that seep sediments are characterized by high horizontal and vertical heterogeneity (Dando et al., 1994a; Treude et al., 2003b). Only a more area-wide sampling strategy could probably reveal statistically significant trends.

When compared to deep-sea seep environments with finegrained sediments (Table 2), the total integrated methanotrophy found at Brian Seep was similar to that of some habitats of the Håkon Mosby Mud Volcano, (Niemann et al., 2006), and the Gulf of Mexico (Joye et al., 2004). In these two habitats AOM is rather restricted. At the Håkon Mosby Mud Volcano, sulfate penetration into the sediment is limited due to high fluid flux from below (Niemann et al., 2006). In the Gulf of Mexico, oil is preferred over methane degradation by sulfate reducers (Joye et al., 2004). In comparison with sites featuring near-surface methane hydrates without oil (Hydrate Ridge, Treude et al., 2003b), however, methanotrophic rates were much lower (1-2 orders of magnitudes) at Brian Seep. An explanation for such a relatively low methane turnover could be that the transport of methane gas in permeable sediments is much more channelized through a connected network of gas voids (Stöhr and Khalili, 2006). The overall low methane concentrations observed in the sediments surrounding the vents would be explained if only a minor fraction of the gas venting through the sandy seabed actually dissolves into the adjacent porewater. This hypothesis is supported by the relatively high methane content $(91 \%$ Kinnaman et al., 2010) of gas entering the water column. If major parts of methane would dissolve into the porewater during its movement through the sediment, we would expect a stronger replacement of methane in the free gas phase by other components such as $\mathrm{N}_{2}, \mathrm{CO}_{2}$, or $\mathrm{H}_{2} \mathrm{~S}$, (McGinnis et al., 2006). 
The long-term effect of such a channelized methane gas stream with restricted dissolution into the porewater can be seen, e.g., in the Kattegat (Baltic Sea). Here, single eroded pillars of carbonate remain as a result of methanotrophy concentrated directly around gas vents (Jensen et al., 1992). Methane, which is seeping through such permeable sediment, might therefore pass the microbial methane filter to a larger extent. At sites bearing extensive near-surface methane hydrates, on the other hand, porewater methane is in equilibrium with the gas hydrates (Luff and Wallmann, 2003). Here, dissolved methane is constantly recharged from the hydrates when removed by consumption or diffusion, thereby fueling higher and more complete methane turnover over larger areas (Treude et al., 2003b). Furthermore, more methane can dissolve into the porewater compared to shallow coastal environments at greater water depth, i.e. under high hydrostatic pressure (Duan and Mao, 2006). More dissolved methane facilitates higher methane turnover rates (Nauhaus et al., 2007; Nauhaus et al., 2002). In this study, the aerobic methane turnover could be strongly underestimated, since oxygen concentrations most likely declined in the cores during the long incubations needed for measurements with radio-labeled methane. Anaerobic methane turnover may continue below the upper sand burden at Brian Seep, i.e. inside the gravel bed. Sulfate, the electron acceptor for AOM, remained basically unchanged (25-28 mM) with respect to seawater levels in the top $15 \mathrm{~cm}$ of the sediment. This situation is different in comparison to many non-bioturbated fine-grained seep sediments where AOM is often restricted to the top $10-20 \mathrm{~cm}$ due to fast sulfate depletion (Table 2). In the Tommeliten area (North Sea, seepage through permeable sands), sulfate remained stable within the upper $\sim 1.70 \mathrm{~m}$ (Niemann et al., 2005). It was eventually consumed by AOM in a distinct zone between silt/clay and marl sediment (between 1.70 and $2.50 \mathrm{~m}$ depth). The hot spot of AOM activity was located below a layer of methanederived authigenic carbonates. Likewise, methane-derived authigenic carbonates were found below the sand burden at Brian Seeps (Kinnaman et al., 2010). However, since we know only little about the transport mechanisms and geochemistry within the gravel bed of Brian Seep, the presence of AOM remains speculative. It is also conceivable that deep injection, e.g., of groundwater, could have a negative impact on AOM activity at depth (Simmons, 1992). In order to answer the remaining questions, sampling of deeper sediment layers would be needed, which remains a challenging task in these areas. Techniques such as vibro-coring could retrieve the actual sediment, which is needed for direct turnover rate measurement, but would heavily disturb porewater geochemistry. Non-invasive techniques, such as peepers (Dattagupta et al., 2007), would produce reliable vertical geochemical profiles but without sediment retrieval.
Acknowledgements. We greatly thank D. Valentine and F. Kinnaman from UCSB for logistical support during joint field trips to Brian Seep and for data discussions. We also acknowledge D. Farrar, S. Anderson, and E. Hessel from UCSB for support during SCUBA dives. K. Stange and B. Domeyer from IFM-GEOMAR are thanked for measuring $\delta^{13} \mathrm{C}$-values of methane and sulfate concentrations, respectively. We thank the two reviewers, P. Dando and H. Røy, for very constructive comments and discussions. This work was funded by the University of Southern California (USC) and the German Research Foundation (DFG, Fellowship No. Tr 867/1-1).

Edited by: A. Boetius

\section{References}

Allen, A. A. and Mikolaj, P. G.: Natural oil seepage at Coal Oil Point, Santa Barbara, California, Science, 170, 974-980, 1970.

Berg, P., Røy, H., Janssen, F., Meyer, V., Jørgensen, B. B., Huettel, M., and De Beer, D.: Oxygen uptake by aquatic sediments measured with a novel nin-invasive eddy-correlation technique, Mar. Ecol. Prog. Ser., 261, 75-83, 2003.

Boetius, A., Ravenschlag, K., Schubert, C. J., Rickert, D., Widdel, F., Giesecke, A., Amann, R., Jørgensen, B. B., Witte, U., and Pfannkuche, O.: A marine microbial consortium apparently mediating anaerobic oxidation of methane, Nature, 407, 623-626, 2000.

Boetius, A. and Suess, E.: Hydrate Ridge: a natural laboratory for the study of microbial life fueld by methane from near-surface gas hydrates, Chem. Geol., 205, 291-310, 2004.

Boles, J. R. and Clark, J. F.: Temporal variation in natural methane seep rate due to tides, Coal Oil Point area, California, J. Geophys. Res., 106, 27077-27086, 2001.

Cline, J. D.: Spectrophometric determination of hydrogen sulfide in natural waters, Limnol. Oceanogr., 14, 454-458, 1969.

Dando, P. R., O’Hara, S. C. M., Schuster, U., Taylor, L. J., Clayton, C. J., Baylis, S., and Laier, T.: Gas seepage from carbonatecemented sandstone reef on the Kattegat coast of Denmark, Mar. Petr. Geol., 11, 182-189, 1994a.

Dattagupta, S., Telesnicki, G., Luley, K., Predmore, B., McGinley, M., and Fisher, C. R.: Submersible operated peepers for collecting porewater from deep-sea sediments, Limnol. Oceanogr. Methods, 5, 263-268, 2007.

Duan, Z. and Mao, S.: A thermodynamic model for calculating methane solubility, density and gas phase composition of methane-bearing aqueous fluids from 273 to $523 \mathrm{~K}$ and from 1 to 2000 bar, Geochim. Cosmochim. Acta, 70, 3369-3386, 2006.

Hall, P. O. J. and Aller, R. C.: Rapid small-volume flow injection analysis for $\sum \mathrm{CO}_{2}$ and $\mathrm{NH} 4+$ in marine and fresh waters, Limnol. Oceanogr., 37, 1113-1119, 1992.

Hinrichs, K.-U., Hayes, J. M., Sylva, S. P., Brewer, P. G., and De Long, E. F.: Methane-consuming archaebacteria in marine sediments, nature, 398, 802-805, 1999.

Hornafius, J. S., Quigley, D., and Luyendyk, B. P.: The world's most spectacular marine hydrocarbon seeps (Coal Oil Point, Santa Barbara Channel, California): quantification of emissions, J. Geophys. Res., 104, 20703-20711, 1999.

Huettel, M. and Gust, G.: Impact of bioroughness on intertidal solute exchange in permeable sediments, Mar. Ecol. Prog. Ser., 89, 
253-267, 1992.

Huettel, M., Ziebis, W., Forster, S., and Luther, I. G. W.: Advective transport affecting metal and nutrient distribution and interfacial fluxes in permeable sediments, Geochim. Cosmochim. Ac., 62, 613-631, 1998.

Huettel, M., Røy, H., Precht, E., and Ehrenhaus, S.: Hydrodynamical impact on biogeochemical processes in aquatic sediments, Hydrobiologia, 494, 231-236, 2003.

Jensen, P., Aagaard, I., Burke, R. A., Jr., Dando, P. R., Jørgensen, N. O., Kuijpers, A., Laier, T., O'Hara, S. C. M.-., and Schmaljohann, R.: "Bubbling reefs" in the Kattegat: submarine landscapes of carbonate-cemented rocks support a diverse ecosystem at methane seeps, Mar. Ecol. Prog. Ser., 83, 103-112, 1992.

Jeroschewsky, P., Steuckart, C., and Kuehl, M.: An amperometric microsensor for the determination af $\mathrm{H} 2 \mathrm{~S}$ in aquatic environments, Anal. Chem., 68, 4351-4357, 1996.

Jørgensen, B. B.: A comparison of methods for the quantification of bacterial sulphate reduction in coastal marine sediments: I. Measurements with radiotracer techniques, Geomicrobiol. J., 1, 11-27, 1978.

Jørgensen, B. B.: Sulfate reduction and thiosulfate transformations in a cyanobacterial mat during a diel oxygen cycle, FEMS Microb. Ecol., 13, 303-312, 1994.

Jørgensen, B. B., Glud, R. N., and Holby, O.: Oxygen distribution and bioirrigation in Arctic fjord sediments (Svalbard, Barents Sea), Mar. Ecol. Prog. Ser., 292, 85-95, 2005.

Joye, S. B., Boetius, A., Orcutt, B. N., Montoya, J. P., Schulz, H. N., Erickson, M. J., and Logo, S. K.: The anaerobic oxidation of methane and sulfate reduction in sediments from Gulf of Mexico cold seeps, Chem. Geol., 205, 219-238, 2004.

Kallmeyer, J., Ferdelman, T. G., Weber, A., Fossing, H., and Jørgensen, B. B.: A cold chromium distillation procedure for radiolabeled sulfide applied to sulfate reduction measurements, Limnol. Oceanogr.: Methods, 2, 171-180, 2004.

Kinnaman, F. S., Valentine, D. L., and Tyler, P. A.: Carbon and hydrogen isotope fractionation accosiated with the aerobic microbial oxidation of methane, ethane, propane and butane, Geochim. Cosmochim. Ac., 71, 271-283, 2007.

Kinnaman, F. S., Kimball, J. B., Busso, L., Birgel, D., Ding, H., Hinrichs, K.-U., and Valentine, D. L.: Gas flux and carbonate occurence at a shallow seep of thermogenic natural gas, GeoMar. Lett., 30, 355-365, 2010.

Krumbein, W. C. and Monk, G. D.: Permeability as a function of the size parameters of unconsolidated sand, Trans. Am. Inst. Min. Metall Petr. Eng., 151, 153-163, 1943.

Kühl, M., Steuckart, C., Eickert, G. and Jeroschewsky, P.: A H2S microsensor for profiling biofilms and sediments: application in an acidic lake sediment, Aquat. Microb. Ecol., 15, 201-209, 1998.

Luff, R., and Wallmann, K.: Fluid flow, methane fluxes, carbonate precipitation and biogeochemical turnover in gas hydrate-bearing sediments at Hydrate Ridge, Cascadia Margin: Numerical modeling and mass balances, Geochim. Cosmochim. Ac., 67, 34033421, 2003.

Mau, S., Valentine, D. L., Clark, J. F., Reed, J., and Camilli, R.: Dissolved methane distribution and air-sea flux in the plume of a massive seep field, Coal Oil Point, California, Geophys. Res. Lett., 43, L22603, doi:10.1029/2007GL031344, 2007.

McGinnis, D. F., Greinert, J., Artemov, Y., Beaubien, S. E., and
Wüest, A.: Fate of rising methane bubbbles in stratified waters: How much methane reaches the atmosphere?, J. Geophys. Res., 111, C09007, doi:10.1029/2005JC003183, 2006.

Nauhaus, K., Boetius, A., Krüger, M., and Widdel, F.: In vitro demonstration of anaerobic oxidation of methane coupled to sulphate reduction in sediment from marine gas hydrate area, Environ. Microbiol., 4, 298-305, 2002.

Nauhaus, K., Albrecht, M., Elvert, M., Boetius, A., and Widdel, F.: In vitro cell growth of marine archaeal-bacterial consortia during anaerobic oxidation of methane with sulfate, Environ. Microbiol., 9, 187-196, 2007.

Niemann, H., Elvert, M., Hovland, M., Orcutt, B., Judd, A., Suck, I., Gutt, J., Joye, S., Damm, E., Finster, K., and Boetius, A.: Methane emission and consumption at a North Sea gas seep (Tommeliten area), Biogeosciences, 2, 335-351, doi:10.5194/bg-2-335-2005, 2005.

Niemann, H., Lösekann, T., De Beer, D., Elvert, M., Nadalig, T., Knittel, K., Aman, A., Sauter, E. J., Schlüter, M., Klages, M., Foucher, J.-P., and Boetius, A.: Novel microbial communities of the Haakon Mosby mud volcano and their role as a methane sink, Nature, 443, 854-858, 2006.

O’Hara, S. C. M., Dando, P. R., Schuster, U., Bennis, A., Boyle, J. D., Chui, F. T. W., Hatherell, T. V. J., Niven, S. J., and Yalor, L. J.: Gas seep induced interstitial water circulation: observations and environmental impliations, Cont. Shelf Res., 15, 931-948, 1995.

Orcutt, B. N., Samarkin, V., Boetius, A., and Joye, S. B.: On the relationsship between methane production and oxidation by anaerobic methanotrophic communities from cold seepd of the Gulf of Mexico, Environ. Microbiol., 10, 1108-1117, 2008.

Orcutt, E., Boetius, A., Elvert, M., Samarkin, V., and Joye, S. B. Molecular biogeochemistry of sulfate reduction, methanogenesis and anaerobic oxidation of methane at Gulf of Mexico cold seeps, Geochim. Cosmochim. Ac., 69, 4267-4281, 2005.

Precht, E., Franke, U., Polerecky, L., and Huettel, M.: Oxygen dynamics in permeable sediments with wave-driven pore water exchange, Limnol. Oceanogr., 49, 693-705, 2004.

Revsbech, N. P.: An oxygen microelectrode with a guard cathode, Limnol. Oceanogr., 34, 474-478, 1989.

Rice, A. L., Gotoh, A. A., Ajie, H. O., and Tyler, S. C.: Highprecision continuous-flow measurements of $\mathrm{d} 13 \mathrm{C}$ and $\mathrm{dD}$ of atmospheric CH4, Anal. Chem., 73, 4104-4110, 2001.

Rusch, A., Forster, S., and Huettel, M.: Bacteria, diatoms and detritus in an intertidal sandflat subject to advective transort across the water-sediment interface, Biogeochemistry, 55, 1-27, 2001.

Sahling, H., Rickert, D., Raymond, W. L., Linke, P., and Suess, E.: Macrofaunal community structure and sulfide flux at gas hydrate deposits from the Cascadia convergent margin, NE Pacific, Mar. Ecol. Prog. Ser., 231, 121-138, 2002.

Seeberg-Elverfeldt, J., Schlüter, M., Feseker, T., and Kölling, M.: Rhizon sampling of porewater near the sediment-water interface of aquatic systems, Limnol. Oceanogr.: Methods, 3, 361-371, 2005.

Shotbolt, L.: Pore water sampling from lake and estuary sediments using Rhizon samplers, J. Paleolimnol., 44, 695-700, 2010.

Simmons, G. M. J.: Importance of submarine groudwater discharge (SGWD) and seawater cycling to mateial flux across sediment/water interfaces in marine environments, Mar. Ecol. Prog. Ser., 84, 173-184, 1992. 
Snaidr, J., Amann, R., Huber, I., Ludwig, W., and Schleifer, K. H.: Phylogenetic analysis and in situ identification of bacteria in activated sludge, Appl. Environ. Microbiol., 65, 3976-3981, 1997.

Soltwedel, T., Portnova, D., Kolar, I., Mokievsky, V., and Schewe, I.: The small-sized benthic biota of the Haakon Mosby Mud Volcano (SW Barents Sea slope), J. Mar. Systems, 55, 271-290, 2005.

Sommer, S., Pfannkuche, O., Linke, P., Luff, R., Greinert, J., Drews, M., Gubsch, S., Pieper, M., Poser, M., and Viergutz, T.: Efficiency of the benthic filter: Biological control of the emission of dissolved methane from sediments containing shallow gas hydrates at Hydrate Ridge, Global Biogeochem. Cy., 20, 1-14, 2006.

Sommer, S., Linke, P., Pfannkuche, O., Niemann, H., and Treude, T.: Benthic respiration in a seep habitat dominated by dense beds of ampharetid polychaetes at the Hikurangi Margin (New Zealand), Mar. Geol., 272(2010), 223-232, doi:10.1016/j.margeo.2009.1006.1003, 2009.

Stöhr, M. and Khalili, A.: Dynamic regimes of buoyancy-affected two-phase flow in unconsolidated porous media, Phys. Rev., 73, 03630, doi:10.1103/PhysRevE.73.036301, 2006.

Treude, T.: Anaerobic oxidation of methane in marine sediments, Fachbereich Biologie/Chemie, Universität Bremen, 252 pp., accessible at http://elib.suub.uni-bremen.de/ publications/dissertations/E-Diss845_treude.pdf, 2003a.
Treude, T., Boetius, A., Knittel, K., Wallmann, K., and Jørgensen, B. B.: Anaerobic oxidation of methane above gas hydrates at Hydrate Ridge, NE Pacific Ocean, Mar. Ecol. Prog. Ser., 264, 1-14, 2003b.

Treude, T., Knittel, K., Blumenberg, M., Seifert, R., and Boetius, A.: Subsurface microbial methanotrophic mats in the Black Sea, Appl. Environ. Microbiol., 71, 6375-6378, 2005a.

Treude, T., Krüger, M., Boetius, A., and Jørgensen, B. B.: Environmental control on anaerobic oxidation of methane in the gassy sediments of Eckernförde Bay (German Baltic), Limnol. Oceanogr., 50, 1771-1786, 2005 b.

Valentine, D. L., Reddy, C. A., Farwell, C., Hill, T. M., Pizarro, O., Yoerger, D. R., Camilli, R., Nelson, R. K., Peacock, E. E., Bagby, S. C., Clarke, B. A., Roman, C. N., and Soloway, M.: Asphalt volcanoes as potential source of methane to late Pleistocene coastal waters, Nat. Geosci., 3, 345-348, (25 April 2010), doi:10.1038/ngeo848, 2010.

Yamamoto, S., Alcauskas, J. B., and Crozier, T. E.: Solubility of methane in distilled water and seawater, J. Chem. Eng. Data, 21, 78-80, 1976.

Ziebis, W., Huettel, M., and Forster, S.: The impact of biogenic sediment topography on oxygen fluxes in permeable sediments, Mar. Ecol. Prog. Ser., 140, 227-237, 1996. 